\title{
Bahasa, Pikiran, dan Kebudayaan
}

\author{
Muhamad Sarifuddin \\ Email : dgreatngloriousone@yahoo.com
}

\begin{abstract}
Abstrak. Kajian ini berfokus pada Bahasa, Pikiran, dan Kebudayaan. Sebuah masyarakat tidak dapat terbentuk tanpa komunikasi. Ini diperlukan, bahwa manusia harus menemukan sesuatu diluar symbol dimana dapat mengungkapkan ide yang membuatnya berpikir, sehingga dapat dipahami oleh yang lain. Sesuatu itu adalah pengalaman, lingkungan, dan budaya. Berpikir digunakan untuk memunculkan suatu tanda yang dapat digunakan untuk berkomunikasi dengan manusia lain, serta membentuk persepsi suatu masyarakat. Ketiganya tidak dapat terlepas dan berdiri sendiri. Berpikir merupakan suatu proses awal dalam membentuk bahasa dan budaya. Ada 4 teori yang diadankan dalam topik yang dibahas oleh oleh penulis yaitu : 1. ujaran terlepas dari berpikir, 2. bahasa terlepas dari berpikir, 3. bukan bahasa yang menentukan persepsi kita, tetapi lingkungan dan pengalaman, 4.bukan bahasa yang menentukan pandangan kita terhadap dunia. Perbedaan pendapat dari 4 teori yang diajukan adalah bahwa bahasa (dalam hal ini tatabahasa) dapat merepresentasikan semua makna yang ada, padahal kenyataannya tidak. Pemberian makna membutuhkan sumber nonlinguistik seperti pengalaman, situasi, dan manah. Kesalahan behavioristik juga membedakan adanya superior dalam bahasa, padahal hal itu tidak ada. Masyarakat tetap mempunyai konsep yang ada di masyarakat lain, hanya mereka tidak mempunyai cukup leksikon sebagai penandanya.
\end{abstract}

Key words: Bahasa, Pikiran dan Kebudayaan

\section{PENDAHULUAN}

Masyarakat Amerik1, setelah terjadi perbedaan cara pandang politik, mempercayai bahwa bahasa Jerman, bagaimanapun dinyatakan salah dan tidak layak diajarkan pada anak-anak dengan alasan akan mempengaruhi cara pandang kebangsaan dan nasionalisme anak

Diceritakan bahwa di negara Hamilton pada tahun 1920 terjadi penahanan seorang guru sekolah minggu bernama Robert Meyer karena mengajarkan cerita Bibel dengan bahasa Jerman pada anak berusia 10 tahun. Di Negara tersebut terdapat peraturan bahwa tidak boleh mengajarkan bahasa asing pada anak yang berusia kurang dari 13 tahun. Acuan yang digunakan pengacara-pengacara Meyer adalah pernyataan filsuf Jerman Wilhelm von Humboldt bahwa sebuah bakasa secara alami mencerminkan spirit dan karakter kebangssan seseorang

Sarjana Jerman abad ke 19 ini berpendapat bahwa pemikiran manusia bergantung pada bahasa. Dengan kata lain, menurut dia bahasalah yang menentukan pandangan hidup dan budaya suatu masyarakat sehingga apabila seorang ingin memiliki pandangan lain, ia harus belajar bahasa yang lain dulu. Akhirnya, seorang itu akan menganut budaya dan cara berpikir bahasa asing itu. Von Humboldt berpendapat bahwa struktur suatu bahasa menyatakan kehidupan dalam penutur bahasa itu (Chaer, 2003:52).

$$
\text { "Von Humboldt menyatakan }
$$

keragaman bahasa-bahasa di dunia ini mencerminkan adanya keragaman pandangan hidup, tetapi di pihak lain dia berpendapat bahwa yang mendasari tiap bahasa adalah satu sistem-universal yang menggambarkan keunikan intelek manusia. Karena itu, Vou Hamboldt juga sependapat dengan pandangan nasionalis yang mengatakan bahawa bahasa tidaklah dipelajari, tetapi telah ditentukan lebih dahulu (oleh alam) apabila keadaart-keadaan lingkungan yang sesuai terdapat" ( Chae;, 2003:57).

Kembali pada cerita diatas, beberapa kali mengajukan banding akhirnya Meyer mendapatkan keputusan tidak bersalah, dengan pernyataan hakim bahwa mengetahui sebuah bahasa tidak akan membentuk nilai dan kebudayaan dari Negara asal bahasa tersebut (Steinberg, 2001:246)

Cerita tersebut memberikan dua pendapat yang bertentangan yang dapat kita pertanyakan, bahwa pendapat manakah yang benar. Apakah benar, bahasa dapat mempengaruhi pemikiran suatu masyarakat, 
atau bahasa tidak berpengaruh dalam budaya masyarakat, atau budaya masyarakat yang mempengaruhi budaya. Bahasa membentuk budaya, atau bahasa merupakan bentukan dari budaya?

\section{PEMBAHASAN}

Terdapat empat teori tentang pikiran, budaya, dan bahasa yang didukung dan dipertentangkan oleh sejumlah ahli bahasa maupun budaya.

Teori 1: Ujaran penting bagi pemikiran. Berbicara keras digunakan untuk mengungkapkan ide.

Teori 2: Bahasa penting bagi pemikiran. Bagaimana membuat atau memahami bahasa.

Jika tidak membuat atau memahami bahasa, kita tidak dapat mengembangkan pemikiran

Teori 3: Bahasa menentukan atau membentuk persepsi kita pada alam. Pembelajaran

bahasa akan menentukan atau mempengaruhi cara kita memandang dunia fisik,

secara visual, auditorial, dsb

Teori 4: Bahasa menentukan pandangan dunia dari segi budaya. Pembelajaran bahasa akan mempengaruhi cara kita memahami budaya dan dunia kita.

A. Teori mengenai Hubungan antara Bahasa, Pikiran, dan Budaya

1. Dukungan terhadap Teori ini

Teori ini berpangkal dari teori Behaviorisme yang mendasarkan segala sesuatu berasal dari proses rangsang-tanggap dan mengesampingkan mental. Seperti vana diutarakan Watson bahwa manah adalah ketahyulan dan tidak layak dikaji secara ilmiah.

Artinya, pikiran dianggap sebagai sebuah jenis tindakan, tuturan yang berasal dari Speech production. Behaviourists mendukung teori ini dengan berpendapat bahwa pikiran atau kognisi dapat diamati secara fisik atau potensial. Watson, Skinner. Bloomfield menyatakan bahwa pikiran berkembang melalui sejenis tuturan, vaitu berujar dengan mengeluarkan suara, kita rulai untuk berbicara secara sub-vokal atau membuat internal artikulasi. Menurut teori ini, pikiran didefinisikan sebagai tuturan sub-vokal atau tindakan, bukan sesuatu yang berkaitan dengan jiwa seperti yang dipercayai oleh para psikologis secara konvensionil.

John B. Watson (1924): mengembangkan pendapat para psikolog bahwa pikiran hanya berbicara dalam hati kita, diri sendiri saja. Menurut Watson, berbicara dengan mengeluarkan suara atau berkata dalam hati dapat diamati, yaitu sebagai sesuatu yang fisik, sejenis tindakan.

B.F. Skinner (1957): pikiran adalah hanya tindakan - lisan atau tidak, mengatakan dalam hati atau tidak.

Leonard Bloomfield (1961) : orang dapat berpikir dan membaca dalam hati karena -adariya bunyi tuturan yang bisa didengar.

Gilber Ryle (1949): syarat untuk dapat berkata kepada diri sendiri dalam hati adalah terlebih dahulu berbicara secara cerdas dan pernah mendengar serta mengerti orang lain melakukan demikian.

Alvin Liberman(1957): gerakan artikulasi membantu fonetika akustik pendorong dan bahkan persepsi.

2. Sangkalan terhadap teori tersebut

Diajukan 6 keberatan dari teori bahwa ujaran penting bagi pemikiran, yaitu:

a. Anak yang tidak memproduksi ujaran dapat menafsirkan ujaran dan berfikir.

Kemampuan berbicara pada beberapa situasi merupakan indikasi yang bagus dari pengétahuan bahasa, ketidakhadiran kemampian memproduksi ujaran mungkin tidak mengindikasikan kelemahan pengetahuan bahasa. Beberapa orang yang tidak bisa mendengar dilahirkan bisu Mereka dilengkapi seperangkat alat yang dapat menerjemahkan dan memahami pembicaraan orang, tanpa bicara.

Apakah mereka dapat berfikir? Jika seseorang dapat menafsirkan arti sebuah ujaran, maka orang itu pastilah punya kemampuan untuk berfikir. Akan aneh rasanya jika mendapatkan orang yang dapat menafsirkan ujaran tanpa bias berfikir.

b. Pemahaman ujaran, yang terdiri dari pemikiran, dibangun sebelum produksi ujaran padaanak normal. 
Berpikir mendahului produksi ujaran terjadi dalam proses pemerolehan bahasa. Proses penafsiran dan produksi terbangun dalam mode paralel dengan produksi selalu berusaha menjaga pemahaman. Clark and hecht mengemukakan bahwa selama anak menerima bahasa yang ditafsirkan, anak kemudian berusaha mengungkapkannya ke dalam ujaran Anak berusaha mengkoordinasikan produksi dengan sistem yang terbentuk dari penanaman

Penelitian Huttenlocher menemukan bahwa anak 10-13 bulan dapat menafsirkan ujaran pada level diluar apa yanıg diucapkan.

Sachs and Truswell menemukan bahwa anak yang hanya dapat memproduksi ujaran satu kata akan dapat memahami struktur sintaksis yang terdiri lebih dari satu kata.

Steinberg and steinberg ada anak 2 tahun dapat belajar menulis kata frasa, dan kalimat.Anak tidak memproduksi ujaran dengan tujuan komunikasi namun sebagai proses imitasi tanpa kemampuan untuk pemahaman. Disimpulkan bahwa untuk anak normal ataupun bisu tuli, penafsiran ujaran adalah dasar untuk memproduksi ujaran pada manah. Sejak kemampuan menafsirkan ujaran mempengaruhi keberadaan pemikiran, dapat disimpuikan bahwa produksi ujaran terlepas dari pemikiran.

c. Berbicara keras sembari berpikir tentang sesuatu yang berbeda sering terjadi dalam kehidupan.

Dicontohkan bahwa dalam situasi kuliah, saat kita asik mendiskusikan 'pemerolehan bahasa tiba-tiba cuaca yang tadinya cerah berubah mendung dan turun hujan. Kita teringat Cucian seminggu yang dijemur tadi pagi. Dapat dibuktikan bahwa kita dapat berbicara keras tentang suatu hal, dan dalam waktu yang bersamaan kita memikirkan hal lain yang sama sekali tidak berhubungan dengan pembicaraan kehidupan.

\section{d. Berbicara bohong}

Behavioristik menekankan bahwa pikiran sesuai dengan ujaran yang áikeluarkan, dengan kata lain pikiran mempunyai tipe yang sama dengan ujaran yang dikeluarkan. Berbohong merupakan kegiatan bertutur dengan mengingkari kenyataan. Tipe yang dikeluarkan saat berbohong tidak sama dengan pikiran, mengucapkan sesuatu sambil berpikir sesuatu yang berbeda. Perbedaan dengan bukti di atas adalah waktu kebohongan yang kita susun tidak terikat. Misalnya kita bercerita bahwa "Minggu yang lalu saya pergi ke Malioboro", sedangkan kenyataannya hari Minggu kita melakukan kegiatan, misalnya mengepel lantai.

Pikiran penutur pada saat mengucapkan kata tersebut adalah membayangkan kegiatan hari minggunya yang di rumah, sedangkan ujaran yang dilontarkan adalah dia pergi ke Malioboro.

e. Arti dan pikiran hadir tanpa perlakuan Behavioris berpandangan bahwa gerakan tubuh mempengaruhi pikiran, tapi kenyataannya, orang lumpuh dan tidak dapat menggerakkan tubuhnya tetap dapat berpikir.

f. Interpretasi antar bahasa dapat dilakukan. Behavioris menganggap bahwa tidaklah mungkin terjadi orang dapat menginterpretasikan bahasa yang berbeda dalam waktu yang sama. Penerjemah dalam hal ini harus mempresentasikan terjemahannya melalui dua proses, yaitu berpikir dan mengucapkannya dengan keras. Orang dapat menerjemahkan bahasa asing ke dalam bahasa sendiri secara langsung dalam waktu bersamaan. Satu kali proses saja, orang dapat merepresentasikan apa yang diucapkan dalam bahasa yang berbeda.

\section{B. Teori 2: ahasa Mutlak Ada bagi Pemikiran.}

1. Dukungan terhadap teori ini

Sapir, Whorf, dan Vygotsky menyatakan bahwa sistem bahasa diperlukan untuk berpikir. Pendapat mereka dikenal dengan Sapir-Whorf hypothesis:

Strong version : The language we speak determines the way we think. Weak version: The language we speak influences the way we think. 
Strong version ditentang oleh kovecses : jika strong version benar, tidak mungkin orang bisa belajar bahasa asing. Tetapi, banyak orang yang belajar bahasa asing, bahkan beberapa, dan memperoleh kemampuannya - native or hampir native. Jika pikiran kita strictly ditentukan oleh cara berpikir, kita tidak mungkin menerjemahkan suatu bahasa ke bahasa lain.

Weak version : kita coba lihat ini melalui contoh "color terms". Suatu bahasa

membedakan warna 'biru' dan 'hijau', sedangkan terdapat sebuah bahasa lain tıdak seperti itu.Artinya, jika kita memiliki sejumlah kata untuk membedakan warna, kita lebih mudah mengenal perbedaan warna. Sepertinya hypothesis Whorf disini sebagian benar secara.

Edward Safir (1921), mengatakan bahwa perasaan yang dipikirkan adalah khayalan, tanpa bahasa. Artinya, bahasalah yang memungkinkan orang untuk berpikir.umum, (Kovecses, 2006: 34)

Vygotsky(1934), menyatakan bahwa pikiran hanya dapat dideskripsikan dalam kata-kata saja, Pikiran itu dapat muncul melalui bahasa. "Pikiran lahir melalui bahasa. Pada mulanya bahasa dan pikiran berkembang sendiri-sendiri dan tidak saling mempengaruhi;tetapi pada pertumbuhan selanjutnya keduanya saling mempengaruhi; bahasa mempengaruhi pikiran dan pikiran mempengaruhi bahasa" (Carrol, 2004: 60)

Benjamin Whorf (Caroll, 1956), menyatakan bahwa grammar adalah suatu yang membentukkan ide-ide; program dan penunjuk aktivitas mental seseorang. Ideide dirumuskan bukan secara bebas melainkan perumusan ide-ide itu adalah sebagian grammar dan perumusan ide-ide tersebut berbeda-beda antara satu grammar dan lain

2. Sangkalan terhadap teori ini

a. Orang yang tidak bisa mendengar dan berbicara pun dapat berpikir. Helen Keler adalah seorang bisu tuli, dia dapat berpikir, bahkan dapat membuat karangan. Bertolak dari kasus ini, teori Behavioris tentang orang yang tidak dapat berbahasa tidak akan dapat berpikir patah

b. Walaupun seorang multi-lingual, proses berpikir itu tidak tergantung pada bahasa sehingga proses berpikir terjumlah sesuai dengan bahasa yang digunakannya

Sistem bahasa membentuk pikiran, sehingga dipercaya jika orang berbahasa $\mathrm{A}$, maka dia akan berpikir secara $A$, dan orang yang berbicara $B$ akan berpikir secara B. Teori ini dilemahkan dengan adanya keadaan bahwa seorang multilingual akan tetap berpikir dalam satu kerangka pikirnya sendiri, tanpa pengaruh pikiran yang dibawa oleh banyak bahasa tersebut. Contohnya adalah seorang anak yang dalam lingkungan keluarga menggunakan bahasa Jepang dari ibu, Inggris dari ayah, dan Rusia dari nenek, dalam usia 3 tahun sudah dapat menggunakan tiga bahasa. Si anak tetap dapat menggunakan bahasa Inggris seperti anak Amerika di lingkungannya

c. Binatang yang pintar be:tindak tanpa bahasa.

Binatang yang dianggap pintar dapat bertindak secara kreatif. Serangga berpikir secara naluri dan secara alami mempunyai strategi untuk menemukan makanan, membela diri, dan menemukan pasangan, meskipun tanpa bahasa.

d. Berbeda dengan Sapir dan Whorf, Piaget berpendapat justru pikiranlah yang membentuk bahasa. Tanpa bahasa, nikiran tidak akan ada. Pikiranlah yang membentuk aspekaspek sintaksis dan leksikon bahasa. Teori Piaget- teori pertumbuhan kognisi : seorang kanak kanak mempelajari segala sesuatu mengenai dunia melalui tindakan-tindakan dari perilakunya dan kemudian baru melalui bahasa(Carrol 2004: 390). 
Hubungan bahasa dan kegiatankegiatan intelek (pikiran) menurut Piaget:

1. sumber kegiatan intelek tidak terdapat dalam bahasa, tapi dalam periode sensomotorik, yaitu satu sistem skema, dikembangkan secara penuh, dan membuat gambaran dari aspek struktur golongan dan hubungan benda-benda.

2. pembentukan pikiran yang tepat dikemukakan dan berbentuk terjadi pada waktu yang bersamaan dengan pemerolehan bahasa. Keduanya termasuk proses konstitusi fungsi lambang. Fungsi lambang ini ditandai oleh bermacammacam perilaku yang terjadi serentak. Ucapan-ucapan bahasa pertama yang keluar sangat erat hubungannya dan terjadi serentak dengan permainan lambang, peniruan, dan bayangan-bayangan mental.

Manusia telah menerima warisan biologi ketika dilahirkan, berupa kemampuan komunikasi dengan bahasa yang khusus untuk manusia; dan tidak ada hubunganınya dengan kecerdasan atau pemikiran. Kemampuan bahasa ini mempunyai korelasi yang rendah dengan IQ manusia." (Carrol, 2004: 61).Buktinya, anak-anak yang $1 \mathrm{Q}$ nya tinggi atau rendahnya, kemampuan menguasai bahasa cukup baik kecuali sesekali kesalahan. Cacat tidak menimbulkan kerusakan bahasa. Kerusakan bahasa tidak akan menimbulkan kemampuan kognitif yang rendah.

e. Chomsky hipotesis nurani : rumus-rumus struktur bahasa dibawa sejak lahir.

"Bahasa danpemikiran adalah dua buah sistem yang bersaingan yang memiliki keotonomiannya masing-masing. Pada tingkat struktur dalam bahasa di dunia ini sama didasari oleh sistem universal; tetapi pada tingkat struktur-Luar bahasa itu berbeda."(hlm 61).

C. Teori 3 Bahasa menentukan atau membentuk persepsi kita pada alam.

1. Dukungan terhadap teori ini

Whorf, Sapir, Korzybski berpendapat bahwa pengetahuan kata-kata atau sintaksis mempengaruhi persepsi dan pemahaman terhadap alam.

Benjamin Whorf (1956) mengatakan bahwa konsep waktu dan persoalan tidak terbentuk dari pengalaman melainkan bergantung pada bahasa. Jika bahasa berbeda, maka konsep waktu dan sesuatu akan berbeda. Pendapat lain lagi dari Whorf, dia mengemukakan teori kaleng kosong bekas minyak. Kita mendengar istilah kaleng kosong, maka kita merasa tidak ada yang penting dari benda itu, tidak berbahaya. Kenyataan yang ada, kaleng kosong bekas minyak itu masih mengandung sisa gasoline yang dapat meledak dalam temperatur tertentu. Akan berbeda jika kita mendengar istilah kaleng kosong diganti botol gasoline, tentu sikap kita lain juga menanggapinya. Sikap kehati-hatian dan waspada yang akan ditampilkan, bahkan mungkin ketakutan berlebih ketika merasa suhunya memanas. Dapat disimpulkan bahwa menurut Whorf, dalam suatu situasi, bagaimana orang bertindak terpengaruh dari analogy of linguistic formula.

2. Sangkalan terhadap teori ini

a. Persepsi, minat, dan kebutuhan yang menentukan leksikon

Zaman dahulu manusia mempunyai bermacam leksikon untuk menyebutkan segala sesuatu yang berkaitan dengan kuda karena kuda merupakan alat transportasi pada zaman itu. Manusia sekarang tidak banyak tahu tentang kuda namun lebih banyak tahu tentang mobil, karena mereka lebih dekat hubungannya dengan mobil daripada dengan kuda.

Kasus lain adalah ketika anak banyak mengetahui dunia dinosaurus, bukan bahasa yang membentuknya, namun karena ketertarikan dan persepsi merekalah yang menampilkan leksikon tersebut melalui bahasa.

b. Lingkunganlah yang mempengaruhi pada bahasa.

Kaum behavioris memandang bahwa beberapa bahasa yang hanya mempunyai leksikon sedikit tentang alam tidak mempunyai konsep tentang itu.Mereka menganggap masyarakatakan kesulitan mendeskripsikan-atau menggambarkan piersepsi mereka tentang alam. Namun adanya kebutuhan akan merepresentasikan sesuatu hial yang hubungannya dekat dengan manusia dengan bahasa. Meskipun suatu masyarakait tidak mempunyai leksikon untuk menyebutkan sesuatu, 
tetapi mereka tetap mempunyai koinsep. Persepsi membedakan bahasa, bukan bahasa yang membentuk persepsi. Persepsi yang iberbeda membentuk bahasa yang berbeda pula. Misalnya penyebutan warna daun, masyarakat Jawa yang mempunyai leksikon warna hijau akan menyebut hijau, tapi masyarakat Madura akan menyebut dengan biru daun.

Contoh kedua adalah masyarakat eskimo mempunyai leksikon yang lebih banyak mengenai salju dibandingkan masyarakat hawai karena salju bagi masyarakat eskimo dekat hubungannya dan penting daripada masyarakat hawai yiang tidak mengenal salju. Hal ini terjadi bukan karena perbedaan bahasa, namun karena penigalaman dan kebutuhan mereka.

Dapat disimpulkan bahwa lingkungan membentuk bahasia masyarakat.

Contoh ketiga adalah penelitian Rosch: menemukian bahasa Dani, di daerah New Guinea. Dalam Dani language, pembedaan warna itu hanya diua, yaitu mili (dark-cool colors: black, green,blue) dan mola (lightwarm colors: white, red,i yellow).

Masyarakat yang menggunakan bahasa Dani itu kekuriangan kata untuk warna. Heider mengajar warna dasar dan non-dasar kepada beberapa peniutur bahasa Dani dengan menggunakan color chips. Penutur Dani yang bersangkutan dapiat belajar kata-kata untuk warna dasar lebih cepat daripada warna-non dasar. Artinya, colior cognition berpengaruh secara sistematis terhadap color languagewalaupun tidak punya biahasa untuk warna dasar itu. Ini adalah bukti bahwa pikiran yang mempengaruhi bahasa (weiak version of Sapir Whorf dibuktikan salah).

Kay dan Kiempton membandingkan penutur English dan Tarahumara, Mexican Indianilanguaige. Ketika disuruh membedakan warna hijau dan biru, penutur English bisa membeidakannya secara jelas, tetapi penutur Tarahumara tidak bisa. Namun, ketika penuturEnglish dibujuk untuk inenamai suatu warna yang ditengah-tengah hijau dan b.ru dengar: kata baru, miereka juga tidak membedakan warna hijau dan biru. Persepsi terhadap warna ternyata bergantuing pada kata-kata kita pakai (Carol, 2004: 384).

c. Manusia berbeda bukan karena bahasa tetapi karena pengalaman. Contoh: Hopi "Time and event"

Menurut Whorf, karena masyarakat Hopi tidak mempunyai tense untuk membedakan kala, serta sedikit sekali leksikon untuk menghitung waktu dianggap masyarakat hopi tidak mempunyai konsep waktu. Menurut Whorf, tata bahasalah yang menentukan jalan pikiran bukan katakata sehingga Sapir-Whorf mengatakan bahwa kehidupan dan pandangan masyarakat yang ada di Asia Tenggara itu sama karena memiliki struktur bahasa yang sama. Whorf menerapkan hal ini pada perbedaan cara berpikir antara Hopi dan kebudayaan Eropa.

"Kebudayaan Hopi diorganisasi berdasarkan peristiwa-peristiwa, sedangkan kebudayaan Eropa di organisasi berdasi rkan ruang dan waktu. Menurut kebudayaan Hopi kalau satu bibit ditanam maka bibit itu akan tumbuh. Jarak waktu yang diperlukan antara masa menanam dan tumbuh nya bibit tidaklah penting. Yang penting adalah peristiwa menanam dan peristiwa tumbuhnya bibit itu. Sedangkan bagi kebudayaan Eropa jangka waktu itulah yang penting.

Menurut Whorf, inilah bukti bahwa bahasa mereka telah menggariskan realitas hidup dengan cara-cara yang berlainan".

Anggapan ini ditentang oleh Gipper dengan bukti bahwa meskipun hopi tidak mempunyai tenses dalam struktur bahasanya, masyarakat hopi tetap mempunyai perhitungan waktu dengan cara berbeda, misalnya dengan menggunakan bulan, matahari, dan musim. Malotki menyimpulkan bahwa manusia tidak berbeda karena bahasa, tetapi berbeda karena pengalaman.

Seperti dicontohkan di buka pelajaran kita (matahari terbenam, kenyataan 
sebenarnya matahari tetap berposisi sama saja, hanya terlihat terbenam di mata orang sehingga terciptakata 'terbenam' dan orang percaya .matahari itu terbenain.), apabila seorang melihat suatuombak di laut, ia melihat permukaan air yang terus-menerus berubalı dengan gerak naik turun, bukanlah apa yang dinamakan ombak. Jadi, disini seorang itu seolah-olah melihat satu ombak karena bahasa telah menggambarkan begitu kepadanya

d. Kekurangan leksikon bukan karena kekurangan konsep.

Contoh tentang ayam. Dalam bahasa jawa terdapat leksikon untuk membedakan ayam jantan "jago" dan ayam betina "babon", berbeda dengan bahasa Indonesia yang tidak mempunyai leksikon untuk menerangkan kata tersebut. Meskipun bahasa Indonesia kekurangan leksikon untuk mendeskripsikan keadaan ayam, bukan berarti orang Indonesia tidak mempunyai konsep untuk membedakan keadaan ayam tersebut.

e. Pengetahuan mengesampingkan arti katakata yang literal

Kita percaya sesuatu yang sangat berbeda dengan kenyataan Sebenarnya, iaitu yang ditentukan bahasa secara iteral, tetapi pemakaian kata itu secara konsisten tidak akan mengubah kan pikiran yang tnendasari. Suatu hal dikatakan untuk menandai hal lain yang berbeda, sehingga pengetahuan itu tidak sesuai dengan katakata. Contoh bagian ini misalnya dalam memberikan ungkapan saat matahari terbit. semua orang tahu bahwa matahari ,hanya diam dan bumilah yang berputar pada porosnya, namun kita tetap mengatakannya dengan sunrise, atau matahari terbit karena matahari memang terlihat terbit oleh mata kita

f. Multi-lingual tidak berarti memiliki cara berpikir atau persepsi terhadap dunia yang berbeda.

Bukan bahasa yang membedakan persepsinya tetapi persepsi itulah yang membedakan pikiran manusía. Misalnya orang Korea yang belajar bahasa Indonesia dan bahasa Jawa di Indonesia, dia tetap akan mempunyai satu persepsi dari dirinya, tidak

\section{Teori 4. Bahasa Menentukan Pandangan terhadap Dunia dari Segi Budaya}

1. Dukungan terhadap teori ini

Jika bahasa merupakan dasar dari pemikiran, maka mengetahui sebuah bahasa dengan sendirinya akan mempengaruhi satu budaya, kepercayaan, atcu persepsi tentang dunia Seperti pernyataan Von Humboldt bahwa bahasa membentuk karakter dan semangat kebangsaan.

Edward Saphir(1929), menyatakan bahasa menunjukan kebenaran social. Setiap bahasamencerminkan masyarakat yang berbeda, jadi tidak ada bahasa yang mirip yang dapat mencerminkan masyarakat yang sama. Menurut Sapir, kehidupan suatu masyarakat sebagian didirikan di atas sifat-sifat bahasa itu. Oleh karena itulah, tidak ada dua bahasa yang sama sehingga dapat dianggap mewakili satu masyarakat yang sama. Menurut dia, apa yang kita lihat, kita dengar, kita alami, dan kita perbuat adalah karena sifat-sifat bahasa

\begin{tabular}{|c|c|}
\hline $\begin{array}{l}\text { Sapir, } \\
\text { menyatakan } \\
\text { menunjukkan }\end{array}$ & $\begin{array}{l}\text { Whorf, } \\
\text { bahwa sistem } \\
\text { pandangan }\end{array}$ \\
\hline
\end{tabular}

\section{Sanggahan terhadap teori in}

Dikritik Hall(1959) dalara bahasa Hopi tidak ada kata 'bilik' tetapi mereka memiliki "bilik-bilik' dalam rumahnya. Kalau memang bahasa yang menentukan kebudayaan dan pikiran manusia, mengapa tidak ada suatu kata tetapi memiliki suatu budaya yang berkaitan dengan kata itu?

a. Bahasa yang sama, tetapi pandangan terhadap dunia yang berbeda

Dicontohkan disini bahwa adalah seorang keluarga di Amerika yang ibunya tidak mempercayai Tuhan, ayahnya seorang penganut kristiani, anak perempuannya muslim, dan anak lakilakinya Hindu. Jelas disini bahwa dalam penggunaan satu bahasa yang sama, manusia atau masyarakat dapat memiliki pandangan hidup yang berbeda. 
b. Bahasa yang berbeda, tetapi pandangan terhadap dunia yang mirip

Penganut kristiani di dunia ini tersebar dari banyak negara, secara langsung bahasa yang digunakan berbeda. Penyampaian ajaran dan prinsip yang terdapat dalam agama tersebut tetap sama, sehingga membentuk pola pemikiran yang sama pada setiap umatnya, bahkan hari raya yang ditetapkan sama waktunya. Ini terjadi dalam bermacam bahasa manusia.

c. Bahasa yang sama, tetapi pandangan budaya berubah waktu ke waktu

Bahasa cina dari 1000 tahun yang lalu hanya mengalami sedikit perubahan. Namun idealism masyarakatnya sering berganti seiring dengan para pemimpin yang memerintah negara tersebut. China menganut feodalisme di bawah kekaisaran Qing, kapitalisme pada pemerintahan Chiang Kai Shek, serta paham komunis di bawah pimpinan Mao. Memang Bahasa Cina mengalami perubahan, tetapi tidaklah frontal dan hanya signifikan sesuai masa pemerintahan tersebut untuk menyelaraskarı ideology.

e. Satu bahasa dapat mendeskripsikan pandangan yang berbeda-beda

Bahasa Jawa, digunakan untuk menyebarkan berbagai agama di kawasan tanah jawa. Para ustadz berceramah menggunakan bahasa Jawa untuk umatnya, pastor menggunakan bahasa jawa untük menjelaskan injil, budha dan hindu pun menggunakan bahasa jawa. untuk merepresentasikan prinsip agamanya.

f. Multilingual world view

Orang cina yang berpaham komunis, akan tetap berpandangan komunis meskipun dia, bercakap dan berada di tengah Negara Amerika yang berpaham liberal. Pandangan hidup ini melekat pada diri seseorang atau masyarakat, seberapapun banyak bahasa yang dikuasai.

\section{E.Kesalahan Kepercayaan dalam ke empat Teori Tersebut}

1. Analisis bahasa dirasa cukup

Penafsiran secara vocabulary tanpa memandang suatu hal diluar struktur bahasa yang juga harus diperhatikan, dalam hal ini dirasa kurang memuaskan karena makna yang ada tidak cukup merepresentasikan makna yang dimaksud pada sebuah kalimat. Masih diperlukan analisis setingkat lebih daripada analisis secara kebahasaan.

2. Arti kata dipandang secara linguistic dari asalnya

Ada beberapa cara untuk menentukan arti kata, yaitu a) pengalaman dari objek, situasi dan kejadian di dunia mendukung pengertian kata b) pengalaman yang dipikirkan, baik tentang pengucapan artikulasi maupun kejadian juga membentuk arti kata. Berpangkal dari sin dapat disimpulkan bahwa mengartikan sebuah kata akan bergantung pada pengalaman non linguistic. Kelemahan teori Whorf adalah ketika berkeyakinan bahwa hariya orang yang bisa mendengar dan berbicaralah yang dapat memahami arti kata.

Kesalahan dari 4 teori yang diajukan adalah bahwa bahasa (dalam hal ini tatabahasa) dapat merepresentasikan semua makna yang ada, padahal kenyataannya tidak. Pemberian makna membutuhkan sumber nonlinguistik seperti pengalaman, situasi, dan manah. Misalnya kata anjing, menurut pandangan behavioristik telah merepresentasikan bentuk anjing, namun tidak demikian kenyataannya.

3. Adanya bahasa primitive dan tingkat intelegensi manusia yang rendah

Kesalahan behavioristik ju a membedakan adanya superior dalam bahasa, padahal hal itu tidak ada. Masyarakat tetap mempunyai konsep yang ada di masyarakat lain, hanya mereka tidak mempunyai cukup leksikon sebagai penandanya.

\section{F. Teori terbaik 1: Berpikir terlepas dari bahasa}

Bahwa manusia dapat berpikir tanpa harus mengeluarkan suara keras untuk mengekspresikan gagasannya. Berpikir merupakan kegiatan bebas yang tidak terikat pada bahasa yang harus diucapkan. Pemikiran bebas dari bahasa, dan bahasa terlepas dari proses berpikir sehingga fungsi bahasa adalah membentuk arti untuk mengekspresikan dan mengkomunikasikan pikiran. Anak belajar bahasa dari peniruan secara auditory dan visual, sebelum anak dapat berbahasa, anak 
tetap dapat berpikir. Pembentukan proses berpikir mendahului pembentukan proses berbahasa. Prosesnya adalah berpikir, pemahaman ujaran, kemudian baru memproduksi ujaran.

\section{THOUGHT $\rightarrow$ SPEECH \\ UNDERSTANDING $\rightarrow$ SPEECH PRODUCTION}

Kegiatan berpikir yang digarisbawahi dalam teori ini adalah bahwa keberadaan manah, pikiran, dan ide, dan pengaruhnya terhadap perilaku, dalam kaitannya dengan asal pemikiran adalah penting.

\section{G. Teori Terbaik 2: Bahasa dapat membantu mengekspresikan ide baru dan budaya}

1. Bahasa digunakan untuk mengekspresikan ide baru.

Kita sudah mengetahui suatu bahasa. Dari bahasa yang telah kita kuasai tersebut, kita dapat menyampaikan suatu ide yang kita representasikan melalui bahasa. Misalnya saat kita membuat karya tulis ata1 karangan.

2. Bahasa digunakan untuk merubah kepercayaan dan nilai

Ketika suatu paham berdiri pada suatu wilayah, maka nilai, kepercayaan, dan pandangan hidup dapat berubah secara radikal. Bahasa tidak merubah cara berpikirnya, hanya mempengaruhi pandangan dan persepsinya. Misalnya ketika orang merubah pandangan politik atau agamanya, maka akan ada bahasa tertentu yang digunakan untuk memperdalam keyakinannya tersebut.

3. Penggunaan bahasa mer.bantu membangun hak masyarakat sipil dan wanita

Bahasa digunakan sebagai alat komunikasi dapat mengekspresikan emosi. Jika kita tidak membedakan ras, gender, dan etnik, maka bahasa yang digunakan tidak menampak:kan perbedaan dalam hal itu. Misalnya adanya kata chairman dirasa tidak adil, maka munculah kala baru untuk menggantikannya agar terasa setara, dengan chairperson. Kaitannya dengan budaya, persepsi suatu masyarakat memunculkan suatu budaya tertentu, dan bahasa digunakan untuk mengekspresikan nilai yang mereka percayai. Misalnya pada masyarakat Jawa dan Korea, pandangan masyarakat terhadap orangtua harus dihormati. Hal itu memunculkan system honorific pada sapaannya

4. Bahasa digunakan untuk mempertajam ingatan

Kita dapat berbicara dan menulis menggunakan bahasa yang telah kita simpan, kemudian kita ungkapkan ide melalui bahasa. Tanpa bahasa kita tidak dapat mendeskripsikan suatu budaya. Jika suatu masyarakat mempunyai banyak leksikon untuk merepresentasikan sesuatu, maka secara otomatis mereka lebih banyak punya ingatan untuk kata tersebut. Misalnya mahasiswa elektronika akan mempunyai leksikon lebih banyak tentang listrik daripada mahasiswa jurusan sastra, begitupun sebaliknya. Namun hal itu tidak membedakan proses berpikir mereka.

\section{H. Pendapat John Locke}

Sebuah masyarakat tidak dapat terbentuk tanpa komunikasi. Ini diperlukan, bahwa manusia harus menemukan sesuatu diluar symbol dimana dapat mengungkapkan ide yang membuatnya berpikir, sehingga dapat dipahami oleh yang lain. Sesuatu itu adalah pengalaman, lingkungan, dan budaya.

\section{KESIMPULAN}

Berpikir digunakan untuk memunculkan suatu tanda yang dapat digunakan untuk berkomunikasi dengan manusia lain, serta membentuk persepsi suatu masyarakat. Ketiganya tidak dapat terlepas dan berdiri sendiri. Berpikir merupakan suatu proses awal dalam membentuk bahasa dan budaya.

1. ujaran terlepas dari berpikir

2. bahasa terlepas dari berpikir

3. bukan bahasa yang menentukan persepsi kita, tetapi lingkungan dan pengalaman

4. bukan bahasa yang menentukan pandangan kita terhadap dunia

Kesalahan dari 4 teori yang diajukan adalah bahwa bahasa (dalam hal ini tatabahasa) dapat merepresentasikan semua makna yang ada, padahal kenyataannya tidak. Pemberian makna membutuhkan sumber nonlinguistik seperti pengalaman, situasi, dan 
manah. Kesalahan behavioristik juga membedakan adanya superior dalam bahasa, padahal hal itu tidak ada. Masyarakat tetap mempunyai konsep yang ada di masyarakat lain, hanya mereka tidak mempunyai cukup leksikon sebagai penandanya.

\section{DAFTAR PUSTAKA}

Adams, Parveen. 1973. Language in Thinking. United Kingdom: The Chaucer Press.

Carroll, David. 2004. Psychology of Language.United States: Wadsworth. Chaer, Abdul. 2003. Psikolinguistik. Bandung: Rineka Cipta.

Kövecses, Zlotan. 2006. Language, Mind, and Culture. New York:Oxford University Press

Lyons. Jchn. 1971. Introduction to Theoretical Linguistics. New York: Cambridge University

Matsumoto, David, 2004 Pengantar Psikologi Lintas Budaya. Yogyakarta: Pustaka Pelajar Press.

Steinberg, Danny. 2001. Psycholinguistics: Language, Mind and World. England: Pearson Education Limited. 